Egypt. Acad. J. Biolog. Sci., 13(1):17-23 (2020)

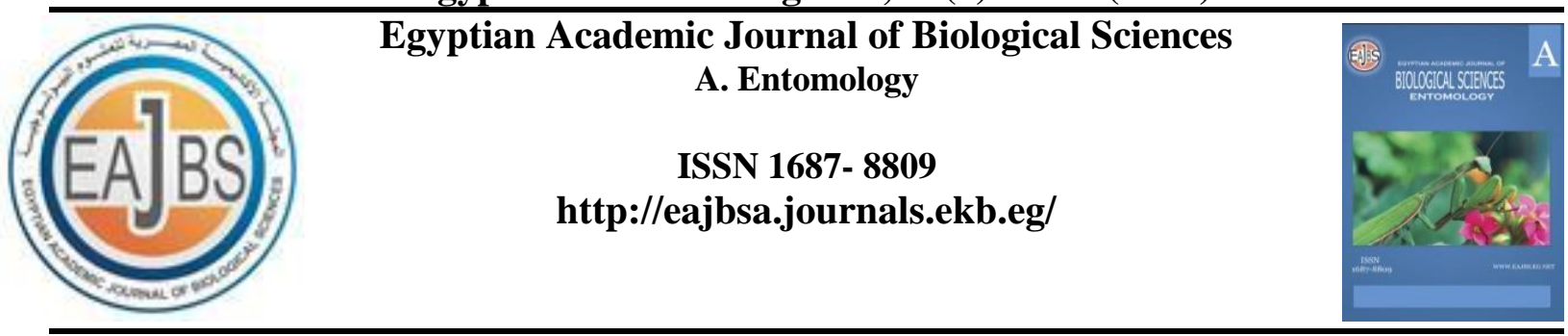

\title{
Effect of Infested Rose Plants by Icerya aegyptiaca on the Physiological and Natural Characteristics of Rose Oil under Glasshouse Conditions
}

\author{
Samia, A. Yassin ${ }^{(1 \& 2)}$ and Emam, A. S. ${ }^{(1)}$ \\ 1-Plant Protection Research Institute, A.R.C., Dokki, Giza, Egypt \\ 2-Faculty of Science and Humanities. Afif. Shaqra University. K.S.A \\ Email: dr.ashrafsalah@yahoo.com
}

\begin{abstract}
ARTICLE INFO
Article History

Received:17/12/2019

Accepted:21/1/2020

Keywords:

Icerya aegyptiaca, physiological and natural characteristics, rose oil, Giza

Governorate

\section{ABSTRACT}

This study was carried out to study the effect of infested rose plants by Icerya aegyptiaca (Douglas) (Margarodidae : Homoptera). (in different stages of infestation) on the physiological and natural characteristics of rose oil at two locations (governorates), International Garden (Cairo Governorate) and El-Orman Garden, (Giza Governorate) under glasshouse conditions during successive seasons 2018.

Data obtained showed that the most important components of rose oil such as (geraniol, citronellol, nerol, stearpoten, phenyl ethanol and bioflavonoids), acids such as Citric acid and Malic acid and vitamins such as vitamin $\mathrm{A}, \mathrm{B}, \mathrm{C}$ and vitamin $\mathrm{D}$ were changed its concentrations as result of infestation by $I$. aegyptiaca. And high infestation by I. aegyptiaca affected concentrations of these components more than medium and low infestation, respectively compared to control. In addition, data obtained showed that the most natural characteristics of rose oil such as volatility, light rotation and refraction value were changed as a result of infestation by I. aegyptiaca but other natural characteristics like freezing point did not change after infestation by $I$. aegyptiaca. And high infestation by $I$. aegyptiaca affected the natural characteristics of rose oil more than medium and low infestation, respectively compared to control.
\end{abstract}

\section{INTRODUCTION}

Rose (Rosa gallica), Fam. Rosacae is one of the most important ornamental plants in Egypt and around all over the world which cultivated both in the open field and under greenhouse conditions. Therefore, it named the king of flowers. It is found from the oldest countries and it is the favorite flower for humans worldwide. Although developing live and high technical but love humans to roses still and increase. The human love for roses due to their beautiful colors, style of flowers, smiles, and tolerant the inferable weather factors. Recently rose cultivated area increased gradually during the last years, especially in the newly reclaimed areas for purposes local consumption and exportation to the foreign markets. So rose became one of the important components for increase income for many countries all over the world, which producing and exporting these roses to different countries, Baydar (2014) and Emam (2009).

Rose plants infested with a large scale of insects belong to many orders and families. 
Icerya aegyptiaca Douglas (Margarodidae : Homoptera) consider one of the most important insects of rose plants which infested its stems, branches, leaves and flowers and also infested rose plants both in open fields and under greenhouses. Jaskiewicz (1997) who reported that the strong infestation by different species of mealy bugs resulted in high deformation of stems, leaves and flowers of rose plants. Derek (2017) in Australia who reported that mealy bug Icerya purshaci is a serious pest on rose plants, and it is reproducing all year round. It feeds mainly on the young stems, branches and leaves and developing on flower buds of roses. The adults and nymphs of mealy bug attack the rose plants and suck cell sap from flowers, tender shoots and buds, ultimately decreasing the market value of rose flowers, infestation with mealy bugs causes badly affects the flowering capacity of plants about 2040\% losses. Labanowski (1989) in Poland reported that mealy bug is the most important insect attacks rose plants.

This study was carried out to study effect of infested rose plants by I. aegyptiaca (in different stages of infestation) on the physiological and natural characteristics of rose oil at two locations (governorates), International Garden (Cairo Governorate) and El-Orman Garden, (Giza Governorate) under glasshouse conditions during successive seasons 2018 Therefore this study divided into two parts, first part study the population fluctuations of $I$. aegyptiaca during successive season 2018 on three varieties (colors) of rose, and the second part included effect of insect infestation by I. aegyptiaca (in different stages of infestation) on the physiological and natural characteristics of rose oil.

\section{MATERIALS AND METHODS}

\section{Experimental Design:}

This study was conducted on rose plants are grown at two locations, International Garden (Cairo Governorate) and El-Orman Garden, (Giza Governorate) under glasshouse conditions during successive seasons 2018. Two glasshouses with an area of $27 \times 45 \mathrm{~m}$ of each one used at the two locations, each glasshouse divided into 9 plots $\left(3 \times 5 \mathrm{~m}^{2}\right)$, three plots for each variety of rose. The first one of these glasshouses contained infested rose plants and the other one left as a control. The first glasshouse was arranged in a randomized block with three replicates to three varieties (colors) of rose, and the second glasshouse was arranged in a randomized block with three replicates as control. The $1^{\text {st }}$ glasshouse was artificially infestation by Icerya aegyptiaca and the $2^{\text {nd }}$ one was left as a control. The two glasshouses were in an area isolated from other trees in the garden. Also, the first glasshouse was isolated from the second one. Rose plants were planted in glasshouse conditions at the same time in November (the planting time of rose plants). All agricultural operations of irrigation and fertilization and others are completely identical in the two glasshouses were done without the application of any insecticide.

Artificially infestation was done by insect I. aegyptiaca in the first glasshouse, with careful observation of the mean numbers of I. aegyptiaca during plant growth period and especially during the flowering stage from February - August and recorded mean numbers of mealybug (adult-nymph) by direct counting by weekly, with examining the second glasshouse free as (control). With checkup the physiological and natural characteristics of rose oil at three levels of infestations during three periods: winter during February month (medium infestation), spring during April month (high infestation) and summer during July month (low infestation).

\section{Effect of Insect Infestation by $I$. aegyptiaca on the Physiological and Natural Characteristics of Rose Oil:}

This study was carried out to study effect of infested rose plants by I. aegyptiaca on the physiological and natural characteristics of rose oil through determination the 
concentrations of most important components of rose oil such as (geraniol, citronellol, nerol, stearpoten, phenyl ethanol and bioflavonoids), acids such as Citric acid and Malic acid and vitamins such as vitamin A, B, C and vitamin D. Also, determination the most important natural characteristics of rose oil such as volatility, light rotation, refraction value and freezing point.

\section{Determination Physiological and Natural Characteristics of Rose Oil: \\ Rose Oil Extraction:}

Rose oil was extracted from $0.5 \mathrm{~kg}$ of fresh tissue of rose petals. The tissues were ground in liquid nitrogen with a mortar and pestle. Then few mls of tris buffer extraction were added (1:2, tissue: buffer). The medium of extraction contained tris-HCL buffer (0.1mM tris, $\mathrm{pH} 7.5,4 \mathrm{mM}$ B-mercaptoethanol, $0.1 \mathrm{mM}$ EDTA-Na $2,10 \mathrm{mM} \mathrm{KCl}$ and $10 \mathrm{mM}$ $\mathrm{MgCl}_{2}$ ). The crude homogenate was centrifuged at $10.000 \mathrm{xg}$ for $20 \mathrm{~min}$. The supernatant was used for gel analysis by SDS-polyacrylamide gel electrophoresis (SDS-PAGE) according to the method of Laemmli (1970)

\section{Loading on a Gel: \\ Gel Preparation:}

Sodium dodecyl sulphate polyacrylamide gel electrophoresis (SDS-PAGE) was performed using $12.5 \%$ acrylamide and $0.8 \%$ bis-acrylamide running gel consisting of 0.375 $\mathrm{M}$ Tris- $\mathrm{HCl}(\mathrm{pH} 8.8)$ and $0.1 \%$ SDS. Stacking gel $(10 \mathrm{~mm})$ was made using $4.5 \%$ acrylamide containing $0.8 \%$ bis-acrylamide in $0.125 \mathrm{M}$ Tris- $\mathrm{HCl}(\mathrm{pH} 6.8)$ and $0.1 \%$ SDS. The electrophoresis buffer contained $0.025 \mathrm{M}$ Tris- $\mathrm{HCl}, 0.19$ glycine and $0.1 \%$ SDS. The samples were homogenized in $0.12 \mathrm{M}$ Tris- $\mathrm{HCl}(\mathrm{pH}$ 6.8), 0.4 SDS, 10 B-mercaptoethanol, $0.02 \%$ bromophenolbule and $20 \%$ glycerol. The samples were then heated for $3 \mathrm{~min}$. in a boiling water bath before centrifugation. The gel was run under cooling at $90 \mathrm{v}$ for the first $15 \mathrm{~min}$, then $120 \mathrm{v}$ the next $0.5 \mathrm{hr}$ and finally $150 \mathrm{v}$ for the remaining $1.5 \mathrm{hr}$. Sheri et al. (2000).

\section{Sample Loading:}

A known volume of rose sample was applied to each well by micropipette. Control wells were loaded with standard markers.

\section{Electrophoresis Conditions:}

The running buffer was poured into a pre-cooled $\left(4^{\circ} \mathrm{C}\right)$ running tank. The running buffer was added in the upper tank just before running so that the gel was completely covered. The electrodes were connected to power supply adjusted at $100 \mathrm{v}$ until the bromophenol blue dye entered the resolving gel and then increased to 250v until the bromophenol blue dye reaches the bottom of the resolving gel.

\section{Gel Analysis:}

Gels were photographed using a Bio-Rad gel documentation system. Data analysis was obtained by Bio-Rad Quantity one Software version 4.0.3, the sugar and protein were analyzed by High-Pressure Liquid Chromatography (HPLC).

\section{Statistical Analysis:}

In these experiments, the effect of the infested rose plants by I. aegyptiaca (in different stages of infestation) on the physiological and natural characteristics of rose oil was subjected to analysis of variance (ANOVA) and the means were compared by L.S.D. test at 0.05 level, using SAS program (SAS Institute, 1988).

\section{RESULTS AND DISCUSSION}

This study was carried out to study effect of infested rose plants by Icerya aegyptiaca (in different stages of infestation) on the physiological and natural characteristics of rose oil at two locations (governorates), International Garden (Cairo Governorate) and El-Orman Garden, (Giza Governorate) under glasshouse conditions during successive seasons 2018. 
Therefore this study divided into two parts, first part study the population fluctuations of $I$. aegyptiaca during successive season 2018 on three varieties (colors) of rose, Carmen (red), Golden gate (yellow) and Dream (pink). And the second part included the effect of infested rose plants by $I$. aegyptiaca (in different stages of infestation) on the physiological and natural characteristics of rose oil.

\section{Population fluctuations of I. aegyptiaca on Rose Plants during 2018 Season:}

Data tabulated in table (1) show that the infestation by I. aegyptiaca adults began to appear in Carmen variety on rose plants on the $1^{\text {st }}$ February with 7.9 adults/plant, then the infestation increased gradually to reach 24.8 adults/plant (activity peak) on the mid of April then the infestation decreased until reached to 3.7 adults/plant on mid of August. As the same trend nymphs began to appear in Carmen variety on the $1^{\text {st }}$ February with 17.7 nymphs/plant, then the infestation increased gradually to reach 46.8 nymphs/plant (activity peak) on the mid of April then the infestation decreased until reached to 6.4 nymphs/plant on mid of August.

Table (1): Population fluctuations of I. aegyptiaca (adults-nymphs) which infested rose plants during 2018 season.

\begin{tabular}{|c|c|c|c|c|c|c|c|c|}
\hline \multirow[t]{2}{*}{ Date } & \multicolumn{2}{|c|}{$\begin{array}{c}\text { Carmen } \\
\text { (Red) }\end{array}$} & \multicolumn{2}{|c|}{$\begin{array}{c}\text { Golden gate } \\
\text { (Yellow) }\end{array}$} & \multicolumn{2}{|c|}{$\begin{array}{l}\text { Dream } \\
\text { (Pink) }\end{array}$} & \multirow{2}{*}{$\begin{array}{l}\text { Mean } \\
\text { Temp. }\end{array}$} & \multirow{2}{*}{$\begin{array}{c}\text { Mean } \\
\text { Hum. \% }\end{array}$} \\
\hline & Adult & Nymph & Adult & Nymph & Adult & Nymph & & \\
\hline $1 / 2 / 2018$ & 7.9 & 17.7 & 9.8 & 19.5 & 6.9 & 14.5 & 17.3 & 73 \\
\hline $15 / 2 / 2018$ & 13.7 & 22.5 & 16.5 & 26.9 & 11.5 & 19.6 & 18.6 & 73 \\
\hline $1 / 3 / 2018$ & 16.9 & 33.7 & 18.9 & 38.5 & 13.4 & 27.8 & 19.7 & 74 \\
\hline $15 / 3 / 2018$ & 19.5 & 38.5 & 20.3 & 41.7 & 16.5 & 33.8 & 18.5 & 71 \\
\hline $1 / 4 / 2018$ & 21.3 & 43.7 & 21.5 & 46.3 & 17.3 & 38.7 & 19.5 & 68 \\
\hline $15 / 4 / 2018$ & 24.8 & 46.8 & 26.3 & 51.7 & 21.5 & 41.5 & 21.7 & 65 \\
\hline $1 / 5 / 2018$ & 19.7 & 38.7 & 22.8 & 43.8 & 17.3 & 36.8 & 23.5 & 63 \\
\hline $15 / 5 / 2018$ & 16.8 & 31.5 & 19.5 & 37.9 & 13.7 & 27.7 & 25.4 & 60 \\
\hline $1 / 6 / 2018$ & 13.9 & 26.7 & 16.7 & 31.7 & 10.8 & 21.5 & 26.3 & 55 \\
\hline $15 / 6 / 2018$ & 12.5 & 21.8 & 14.3 & 26.9 & 8.2 & 17.9 & 27.5 & 47 \\
\hline $1 / 7 / 2018$ & 9.4 & 16.9 & 12.8 & 21.3 & 7.8 & 13.9 & 27.8 & 49 \\
\hline $15 / 7 / 2018$ & 6.8 & 12.6 & 9.7 & 16.8 & 4.6 & 10.7 & 28.6 & 53 \\
\hline $1 / 8 / 2018$ & 4.8 & 10.5 & 6.8 & 13.7 & 3.2 & 7.8 & 29.5 & 58 \\
\hline $15 / 8 / 2018$ & 3.7 & 6.4 & 3.9 & 10.5 & 2.5 & 5.9 & 30.7 & 56 \\
\hline Total & 191.7 & 368.0 & 219.8 & 427.2 & 155.2 & 318.1 & - & - \\
\hline Mean & 13.7 & 26.3 & 15.7 & 30.5 & 11.1 & 22.7 & - & - \\
\hline $\mathbf{F}(\mathbf{0 . 0 5})$ & & & & 5.25 & & & - & - \\
\hline L.S.D & & & & 85 & & & - & - \\
\hline
\end{tabular}

Means within columns bearing different subscripts are significantly different $(P<0.05)$

Whereas for Golden gate variety I. aegyptiaca adults began to appear on rose plants on the $1^{\text {st }}$ February with 9.8 adults/plant, then the infestation increased gradually to reach 26.3 adults/plant (activity peak) on the mid of April then the infestation decreased until reached to 3.9 adults/plant on mid of August. As the same trend nymphs began to appear on rose plants on the $1^{\text {st }}$ February with 19.5 nymphs/plant, then the infestation increased gradually to reach 51.7 nymphs/plant (activity peak) on the mid of April then the infestation decreased until reached to 10.5 nymphs/plant on mid of August.

Also, for Dream variety I. aegyptiaca adults began to appear on rose plants on the $1^{\text {st }}$ February with 6.9 adults/plant, then the infestation increased gradually to reach 21.5 adults/plant (activity peak) on the mid of April then the infestation decreased until reached to 
2.5 adults/plant on mid of August. As the same trend nymphs began to appear on rose plants on the $1^{\text {st }}$ February with 14.5 nymphs/plant, then the infestation increased gradually to reach 41.5 nymphs/plant (activity peak) on the mid of April then the infestation decreased until reached to 5.9 nymphs/plant on mid of August.

The obtained results agree whom those obtained by Mohammad, M., and Al-Mallah (1987) in Iraq who stated that the first appearance of mealy bugs in large numbers was in mid-February, peaked in early April and disappeared completely by mid-June. Jaskiewicz (2003) studied I. purchasi population dynamics and found that maximum numbers of this insect were observed during March-May. Hole et al. (2017) studied the incidence of mealy bugs on 30 rose varieties and found that the pest build-up started in the third week of February, which increased gradually reaching its peak in the fourth week of March and declined thereafter.

Effect of Infested Rose Plants by I. aegyptiaca on the Physiological and Natural Characteristics of Rose Oil:

1- Effect of Infested Rose Plants by I. aegyptiaca (in Different Stages of Infestation) on the Physiological Characteristics of Rose Oil:

Data tabulated from table (2) show comparison between determinations of rose oil components (concentrations) in the rose flowers which infested by I. aegyptiaca in different stages of infestation (low, medium and high infestation) compared to control (non-infested flowers). Data obtained showed that the most important components of rose oil (geraniol, citronellol, nerol, stearpoten, phenyl ethanol and bioflavonoids), acids such as Citric acid and Malic acid and vitamins such as vitamin A, B, C and vitamin D were changed its concentrations after infestation by I. aegyptiaca. And concentrations of these components were more in control compared to its concentrations in infested rose flowers (high, medium and low infestation, respectively).

Statically analysis shows were highly significant differences between concentrations of these components in control compared to its concentrations in infested flowers (high, medium and low infestation), respectively.

Table (2): Determination of rose oil components (concentrations) $\mathrm{mg} / \mathrm{g}$ on the different stages of infestation by I. aegyptiaca during 2018 season.

\begin{tabular}{|c|c|c|c|c|c|c|}
\hline \multirow{2}{*}{ Compounds } & \multicolumn{4}{|c|}{ Concentrations of rose oil components ( $\mathrm{mg} / \mathrm{g})$} & \multirow[b]{2}{*}{$\mathbf{F}(\mathbf{0 . 0 5})$} & \multirow[b]{2}{*}{ L.S.D } \\
\hline & Low infestation & Medium infestation & High infestation & Control & & \\
\hline Geraniol & $32.52^{a}$ & $28.35^{b}$ & $25.13^{c}$ & $37.25^{\mathrm{a}}$ & $24.79 * * *$ & 1.15 \\
\hline Citronellol & $19.28^{b}$ & $15.65^{b}$ & $12.45^{c}$ & $24.35^{\mathrm{a}}$ & $35.21 * *$ & 1.43 \\
\hline Nerol & $17.65^{c}$ & $15.31^{\mathrm{b}}$ & $13.24^{\mathrm{c}}$ & $19.35^{\mathrm{a}}$ & $18.75^{* *}$ & 1.81 \\
\hline Stearpoten & $30.45^{b}$ & $26.34^{b}$ & $22.56^{c}$ & $34.21^{\mathrm{a}}$ & $43.71^{*}$ & 0.15 \\
\hline Phenyl ethanol & $13.92^{\mathrm{a}}$ & $11.87^{\mathrm{d}}$ & $10.55^{\mathrm{c}}$ & $17.67^{2}$ & $21.35^{* *}$ & 1.75 \\
\hline Bioflavonoids & $6.67^{b}$ & $5.23^{b}$ & $4.12^{c}$ & $8.89^{\mathrm{a}}$ & $64.12^{* *}$ & 0.63 \\
\hline Citric acid & $11.21^{\mathrm{b}}$ & $8.67^{6}$ & $5.25^{\mathrm{c}}$ & $13.23^{\mathrm{a}}$ & $34.18^{* * *}$ & 1.52 \\
\hline Malik acid & $7.42^{c}$ & $5.37^{\mathrm{a}}$ & $3.54^{c}$ & $9.84^{\mathrm{a}}$ & $35.21^{* *}$ & 1.26 \\
\hline Vitamin $\mathrm{A}$ & $5.34^{2}$ & $4.45^{b}$ & $3.65^{c}$ & $7.25^{\mathrm{a}}$ & $34.17^{*}$ & 0.08 \\
\hline Vitamin B & $4.12^{2}$ & $3.56^{\mathrm{a}}$ & $2.89^{c}$ & $5.23^{\mathrm{a}}$ & $27.29 * * *$ & 1.15 \\
\hline Vitamin C & $3.65^{2}$ & $2.15^{b}$ & $1.50^{\mathrm{c}}$ & $4.76^{\mathrm{a}}$ & $23.12^{* *}$ & 0.37 \\
\hline Vitamin D & $2.15^{2}$ & $1.86^{b}$ & $.25^{c}$ & $3.75^{\mathrm{a}}$ & $17.24^{*}$ & 1.52 \\
\hline
\end{tabular}

Means within rows bearing different subscripts are significantly different $\quad(\mathbf{P}<0.05)$

\section{2- Effect of Infested Rose Plants by I. aegyptiaca (in Different Stages of Infestation) on the Natural Characteristics of Rose Oil:}

Data tabulated in table (3) show a comparison between natural characteristics of rose oil in rose flowers which infested by $I$. aegyptiaca in different stages of infestation (low, medium and high infestation) compared to control (non-infested). Data showed that the most 
natural characteristics of rose oil such as volatility, light rotation and refraction value were changed as a result of infestation by I. aegyptiaca, but other natural characteristics such as freezing point did not change after infestation by $M$. rosae.

Table (3): Natural characteristics of rose oil as result of infestation by I. aegyptiaca during 2018 season.

\begin{tabular}{|c|c|c|c|c|c|c|}
\hline Characteristics & Low infestation & Medium infestation & High infestation & Control & F(0.05) & L.S.D \\
\hline Volatility & $0.835^{\mathrm{a}}$ & $0.625^{\mathrm{b}}$ & $0.460^{\mathrm{c}}$ & $0.935^{\mathrm{a}}$ & $35.27^{* * *}$ & 0.75 \\
\hline Light rotation & $0.51^{\mathrm{a}}$ & $0.47^{\mathrm{b}}$ & $0.43^{\mathrm{c}}$ & $0.55^{\mathrm{a}}$ & $21.15^{* *}$ & 0.58 \\
\hline Refraction value & $1.415^{\mathrm{a}}$ & $1.400^{\mathrm{b}}$ & $1.345^{\mathrm{c}}$ & $1.465^{\mathrm{a}}$ & $31.28^{* * *}$ & 0.73 \\
\hline Freezing point & $20 \mathrm{C}$ & $20 \mathrm{C}$ & $20 \mathrm{C}$ & $20 \mathrm{C}$ & - & - \\
\hline
\end{tabular}

Means within rows bearing different subscripts are significantly different $\quad(P<0.05)$

Statically analysis shows highly significant differences between natural characteristics (except freezing point) of rose oil in infested rose flowers (high, medium and low infestation) compared to its natural characteristics in control.

The obtained results are in agreement who those obtained by Emam (2009) in Egypt who studied the effect of infestation by I. aegyptiaca on the interior components of rose flowers, and found that natural characteristics of rose oil changed as result to the infestation by this insect. Peng and Miles (1991) studied the changes in the internal components of rose flowers such as rose oil, protein, sugar and vitamins, which infested with some insects and decided that the most effective in these components was the infestation by mealy bugs. Becker and Apel (1992) reported that the decrease in concentrations of rose oil components might be due to the infestation by I. purchasi. Atwal and Dhingra (2018) reported that the infestation rose plants by mealybugs were changed in the concentrations of rose oil components in the rose petals. While Jaskiewicz (2006) studied the changes which happened in protein pattern in the rose petals which infested by mealy bugs.

Also, the obtained results are in agreement with those obtained by Decheva et al. (2015) in Bulgaria who investigated the changes in the rose oil components in flowers of rose plants, and found that the level of 12 rose oil components identified decreased as a result of infestation by I. purchasi.

\section{REFERENCES}

Atwal, A. S. and Dhingra, S. (2018). Biological studies on I. purchasi the common rose aphid on rose plants. Indian J. Entomol., 33(2): 136-141

Baydar, H. (2014). The cultivation and producing rose and rose oil industry in Turkey. Turktarm 5(1): 54-57

Becker, W. and Apel, K. (1992). Isolation and characterization of DNA clone encoding a novel - induced protein of rose oil. Plant Mol. Biol.19: 1065-1067

Decheva, R.; Koseva, D. and Mikhailova, Y. (2015). Some biochemical and histochemical changes in the tissues of the rose during and after dormancy. Fiziologiya na Rasteniyata. 12(3): 76-84, 1986

Emam, A. S. (2009). Effect of insect infestation on some rose plants. Ph.D. Thesis, Fac. AlAzhar Univ., Cairo, Egypt.

Derek, A. (2017). The biology and main causes of changes in number of the I. purchasi on cultivated roses in South Australia. Australian Journal of Zoology 25(2): 269-284

Hole, U. B.; Salunkhe, G. N. and Shirke, M. S. (2017). Effect of meteorological parameters on population dynamics of I. purchasi. Annals of Plant Protection Sciences, 15(1):106-110

Jaskiewicz, B. (1997). Observations on the occurrence on the I. purchasi on bushes of Rosa rugosa Thunb. and Rosa canina L. Folia Horticulturae 9 (1): 25-31 
Jaskiewicz, B. (2003). Population dynamics of I. purchasi inhabiting shrubs of Rosa sp. In the green areas of Lublin. Annales universitatis Mariae Curie EEE, Horticultura 13: 271-278

Jaskiewicz, B. (2006). The effect of the feeding of I. purchasi on the flowering of roses. Acta-Agrobotanica; 59(1): 515-520

Labanowski, G. (1989). Pests of ornamental plants: The I. purchasi Ochrona Roslin 4(2): 3339

Laemmli, U. K. (1970). Cleavage of structural proteins during the assembly of the head of bacteriophage T4. Nature 15(27): $680-685,1970$

Mohammad, M. A. and Al-Mallah, N. M. (1987): Ecological and biological studies on the $I$. purchasi in Mosul region. Arab J. Plant Prot., 5(2): 53-58

Peng, Z. and Miles, P. (1991): Oxidases in the gut of an I. purchasi and their relation to dietary phenolics. Journal of Insect Physiology, 37(10): 779-787.

SAS Institute (1988): SAS/STAT User Guide, Ver. 6. 03. SAS Institute Inc., Cary, North Carolina.

Sheri, L. H.; Necolas, E. S. and Joanna, B. G. (2000). Comparison of protein expressed by Pseudomonas aeruginosa strains representing initial and chronic isolated from a cystic fibrosis: an analysis by 2-D gel electrophoresis and capillary liquid chromatography tandem mass spectrometry. Microbiol. 146: 2495-2508.

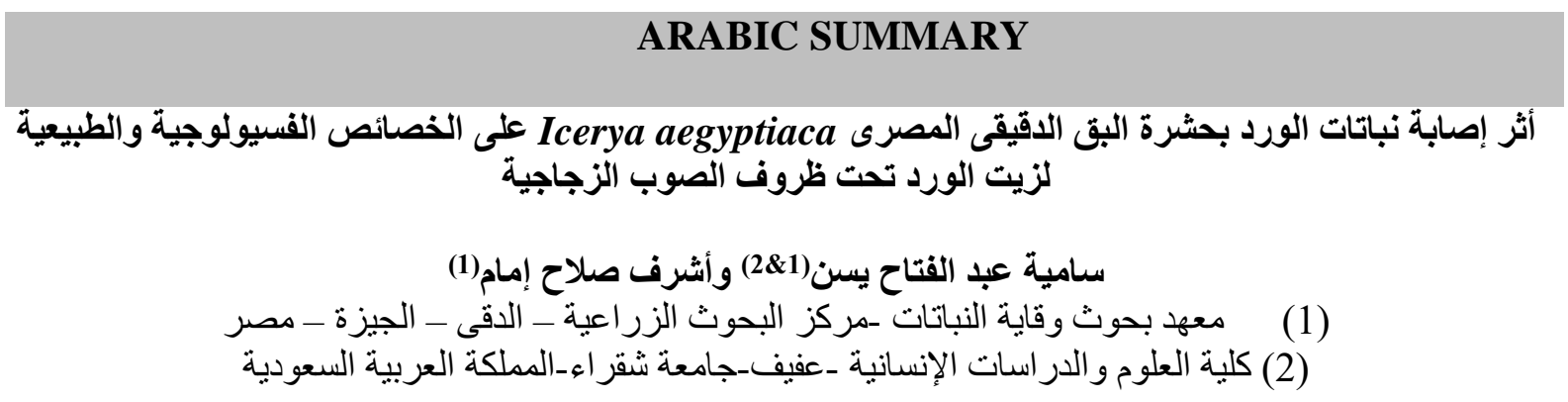

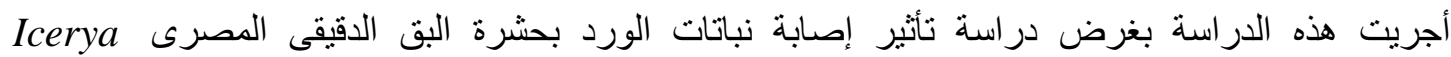
aegyptiaca الدر اسة فى موقعين (محافظتين) مختلفتين الحديقة الدولية (محافظة القاهرة) وحديقة الأورمان (محافظة الجيزة) خلال عام

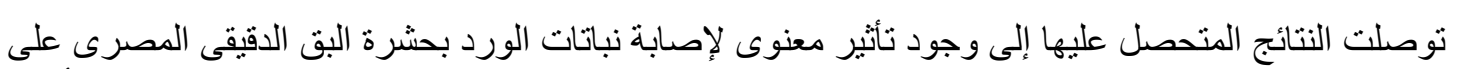
2018

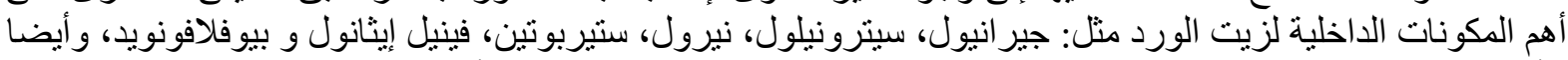

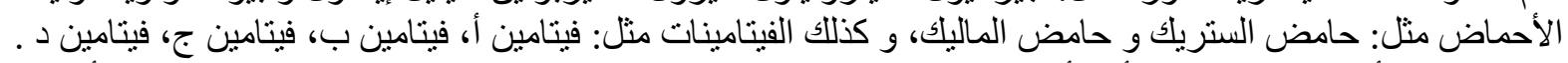

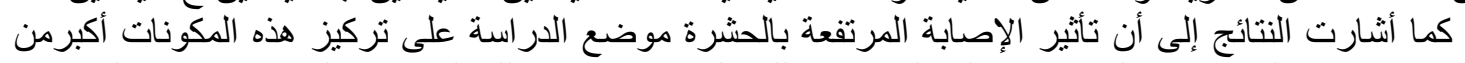

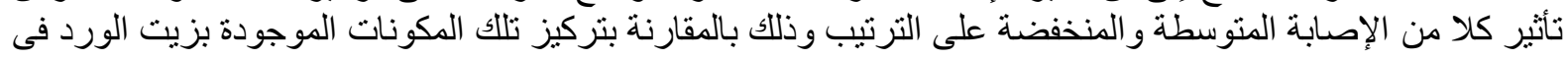

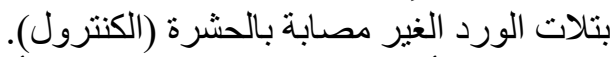

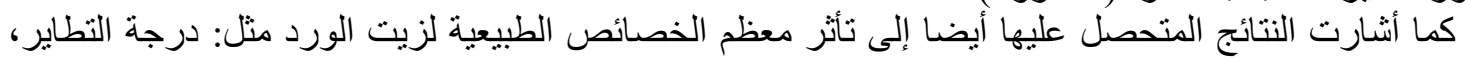

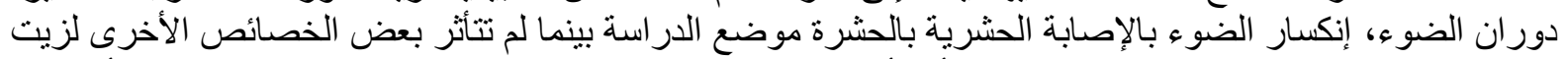

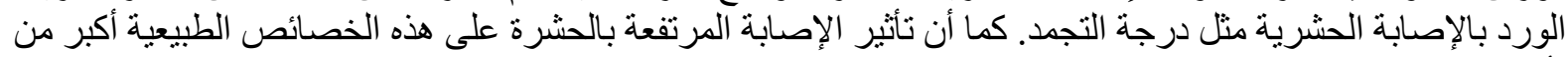

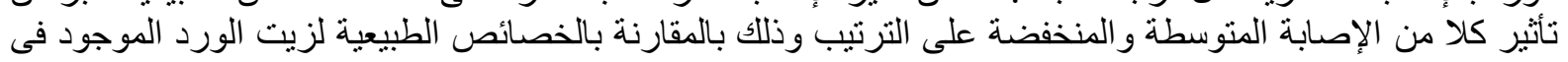
بتلات الورد الغير مصابة بالحشرة (الكنترول). 